SŁAWOMIR KOTYLAK MARIOLA MICHAŁOWSKA WIESŁAW DANIELAK

\title{
Coaching culture in the context of the emergence of creative class
}

Sławomir Kotylak, Ph.D. University of Zielona Góra, Faculty Economic and Management

Mariola Michałowska, Ph.D. University of Zielona Góra,

Faculty Economic and Management

Professor Wiesław Danielak University of Zielona Góra, Faculty Economic and Management
"If you want to be where you've never been, you have to go the way you've never walked. If you want to achieve what you've never had, you have to do what you've never done".

Dominick Coniguliaro

\section{Introduction}

Coaching becomes one of carrying a lot of hope directions in management, and with it - its specific culture, method, philosophy or attitude of coaching. Under this name stands the whole framework of network meanings (Wittgenstein, 2000, p 142). This process, carried out ad extremum, may reach the very core of subjectivity, when it seems entitled to say that what ultimately is at stake-reveals and activates itself - is the essence of a person's identity (individual persons or collective person, e.g. the team, the organization, project, social movement). This is particularly important in the context of the creative class, which will be broadly covered later in this article.

The aim of the paper is to present on the basis of the study of literature the essence of coaching, the creative industries in the modern economy, the culture of coaching in relation to the creative class as well as issues relating to the development of relations between the client and the coach. 
The study also pointed out the differences between coaching, counselling and consulting, the distinguishing features of modern coaching and highlighted the factors affecting the process of shaping the relationship between the client and the coach.

Presented considerations may serve entrepreneurs and managers and employees at different levels to explore knowledge of the creative industries and the role of coaching. Moreover, they can serve as a basis for the preparation of utility solutions that could serve as practical implications in the creation of the development strategy of both entities of creative industry and sectoral partnership in terms of both exo and endogenous.

\section{What is Coaching}

It happens that coaching is confused with advice or consulting. This relationship is however flawed, because the counsellor provides the client with resources and skills that will help the employee to in a higher degree efficiently perform the tasks assigned to him. These activities take the form of specific forms of training and professional development, planning and implementing careers and structuring of work (Drab-Kurowska 2014, p. 91). Unlike the situation in relation to the coach. It is he or she who makes the worker himself come to how to improve their work, so that it is most effective. This is an important distinction, because the performer mastered by a coach is aware that worked out value (product, service) is his merit, and so, identifies with it more, which also affects the greater efficiency and motivation.

This assumption has been described, inter alia, by R. Dilths who writes that individuals' consciousness transformation, together with their simultaneous synergistic integration at levels considered to be higher, results in remarkably profound changes in the cognitive, emotional and behavioural dimension, and therefore in the basic dimensions shaping human inclinations and attitudes. These consequently induce a cascade of effects at lower levels (Dilths 2006, p. 46). This applies to specific values, utilitarian goals and preferences, and what goes with it, efficiency and resource, as well as tools and methods being used. This creates a self-reinforcing spiral of development.

Value added as a side effect of the original process generates a secondary process whose side effects as the new added value induce a process of the third row (Mukoid 2010, p. 2). However, an objective use of coaching as a lever for fast development and using it as a tool to be easily translated into a quantitative growth of indicators, turns out to be a misunderstanding, leading to effects that 
are opposite to what was intended. This fact, as J. Czaplewski (2011, p. 24) writes, directs attention to the usefulness and value of information, in this case coming from coaching.

In this context, it is an appropriate definition of coaching developed by S. Thorpe and J. Clifford (2004, p. 17), according to which coaching is "to help a person in strengthening and improving operations by reflecting on how to apply a particular skill and/or knowledge".

In terms of C. Wilson (2011, p. 414) coaching involves using skills such as: the question of listening and explaining and intentions related to respect, emotional intelligence and building trust (figure 1).

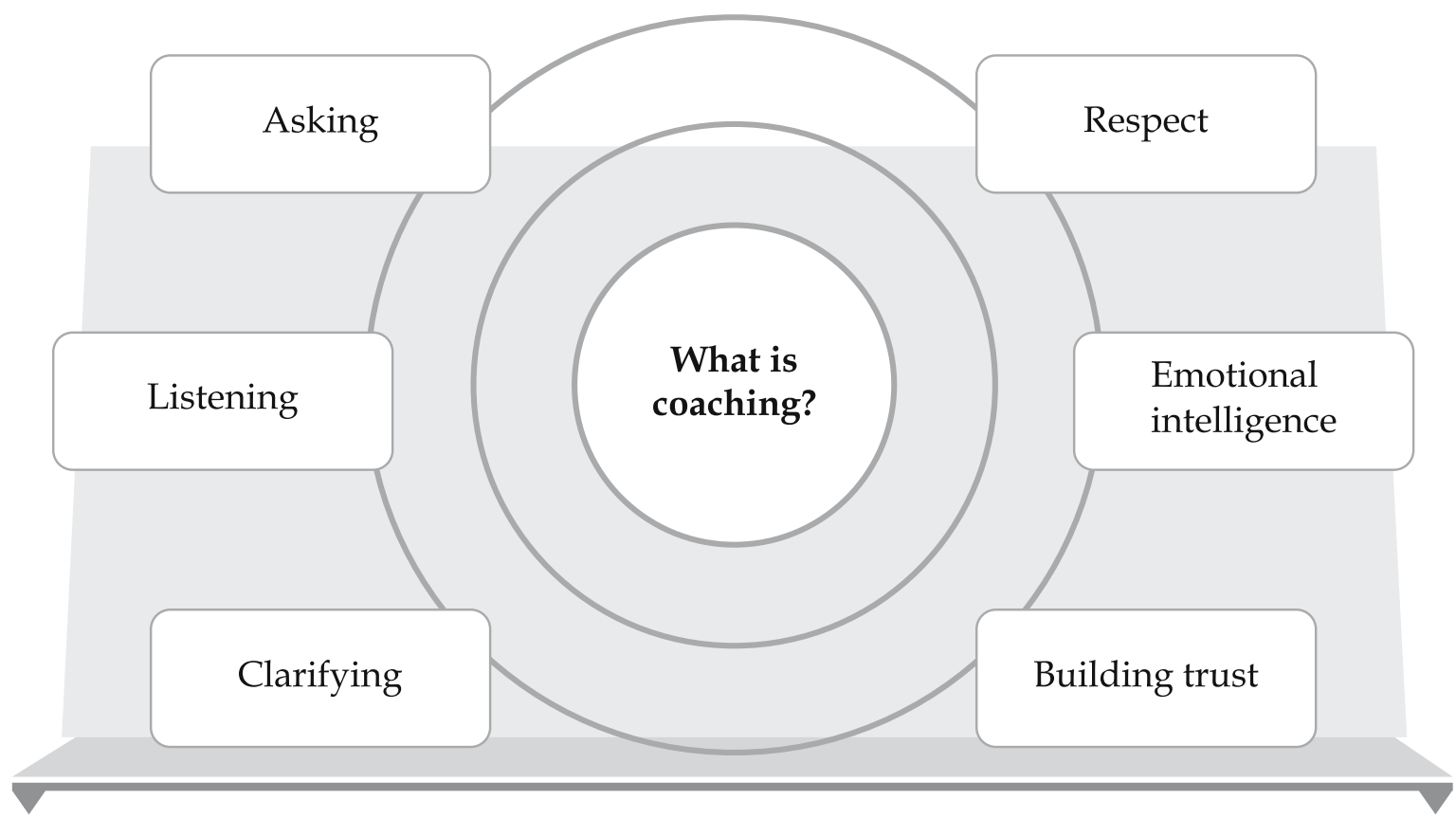

Figure 1. What is coaching?

Source: Wilson C. (2011), Developing a coaching culture, „Industrial and Commercial Training", Vol. 43 Iss. 7, p. 414

In contrast, D. Clutterbuck (2009, p. 16) defines coaching from the perspective of relations, indicating that it is a relationship between the coach and the client, based on cooperation, which leads to the fulfilment of customer's requirements. The goals are determined by the client, who, with the support of the coach, takes very specific actions leading to desired changes in their lives. According to 
D. Clutterbuck (2009, p. 17), the idea is that the customer takes full advantage of their potential and reaches their goals. And they are supported in fulfilling the objectives by the coach through planning strategies.

The indicated definitions identify the most important and distinctive features of coaching. The selected definitions are complemented by the definition of coaching by P. Pilipczuk (2010, p. 102), in terms of which it is a "process, whose main objective is to strengthen and support an independent customer in making the intended changes, based on their own (client) findings, conclusions and resources".

In the literature there are a number of studies whose authors point to the key features of modern coaching. An example is the distinction by D. D. Clutterbuck and Megginson (2004) of ten traits which are key elements of modern coaching (Czarkowska 2011, p. 53). These indicators show that:

1. People have all the resources they need, but do not necessarily have to have a direct conscious access.

2. Human actions (motivation, attention, choices, also omission) are guided by values - but are not necessarily conscious. It happens that people sabotage their own plans, thus realizing the other - unconscious - values and goals.

3 . There are ways to communicate with our unconscious values, resources, personality reserves, allowing their conscious and deliberate use. These methods are developed and used by coaching as a technique of expanding consciousness and exploring access to resources.

4. The reality is a cycle of changes, the changes are in fact inevitable.

5. Man is realized and achieves satisfaction in the conscious, intentional act, which is carrying out the process of a positive change in the existing reality.

6. Achieving the desired results (development, implementation of purposes) is possible. What has been achieved by someone, can also be achieved by others.

7. Effectiveness, as carrying out the intended positive changes, facilitates the use of appropriate methods. These methods are inventorised and developed by coaching as effective action technology.

8. Communication between people takes place at various levels and in many dimensions, and its effects cause a real change both in people and in their relationships, or more broadly - in their environment (the world).

9. Because we communicate, we are in some way related, which, on the one hand, allows intersubjectivity, and on the other, argues for ecology, understood as a dynamic interdependence of various objectives and actions. 
10. Coaching is such a structured, conscious and deliberate practice of communication, whose mission is the ecological transformation of human reality.

These differentiators are of special interest because of their direct relationship with the basics of the theory of creation of creativity centres based on owned and acquired social capital represented by those characterized by a special skill of impact on the environment, as being the basis for social networking in the community. This is a perfect combination of R. Florida (2002) theories relating to the birth of the creative class. In addition, the characteristics of coaching that are mentioned by a number of authors confirm this statement invoking the results of neuroscience (see. Fustec, Fradin 2001) in terms of optimal conditions for the functioning of the human brain (treated as tangible medium of the mind and creativity), but also the social economy and economics action (Łychmus 2010, p. 57), management sciences and sciences about the company and the latest psychology.

In conclusion, we note that, in regard to the creative class, coaching extends its alternative development of people and their organizations, based on the values of communication, acceptance of diversity and individuality, strengthening the sense of subjective efficacy and integrity, while expanding individual consciousness. As a result, it deepens the effect of stimulating creativity, which directly affects the development of the creative class as an essential element of the proper functioning of an important sector of the economy, which is the creative industry.

\section{The definition of creative industries in the modern economy}

Companies forming various sectors of creative industries co-create a new sector of the economy known as the creative economy (Klasik 2009, p. 31). The result of their work are products and services of an intellectual, artistic and scientific character. There is a domination of individual creative work and team cooperation related to research-development and artistic-cultural ventures (Klasik 2009, p. 32).

Creative industries are associated with concepts such as culture and creative industry. The beginning of the research on cultural industries is considered to be the work published in 1947 by T. Adorno and M. Horkheimer (2002, p. 242), who introduced the distinction between "mass culture" and „cultural industry". The first is - according to T. W. Adorno (1999, p. 13) - culture arising spontaneously from the masses themselves, a contemporary form of folk art. 
In contrast, writing about the cultural industry, he stated: Cultural industry varies extremely from [mass culture]. It adds up old habits to a new quality. In all industries products are tailored more or less as planned according to the measure of mass consumption and to a high degree they determine this consumption themselves. The essence of the cultural industries - according to the canonical definition of Adorno - is to impose on customers (consumers) harmonized standards of reception of cultural goods and uniform system of aesthetic judgments (Adorno 1999, p. 14).

In consequence, one began to use the concept of cultural industries in relation to areas in which cultural goods and services are produced and reproduced in an industrial way. Such areas are, for example, radio and television, books and phonography. In this approach it emphasizes the importance of industrial infrastructure, whose state, method of organization and management greatly affect the type and nature of the market offer of the mentioned forms of activity. This has led to a situation in which cultural elements are distinguished not by their culture-creation nature but due to the nature of end products (goods and services) produced with the involvement of human creativity.

The result of discussions conducted by researchers in the context of product or non-product perception of culture are currently three perspectives. The first one and at the same time the widest, is characteristic of the theory of cultural studies and social sciences, on the basis of which the concept of culture refers to the total number of human practices and products of symbolic communication socially accepted and recognized for their contribution to the development of human civilization. In the second, narrower sense, the notion of culture refers to the broader art, taking into account only its size as the creative process culminating in the creation of a tangible example of the creativity of the creator. The third approach refers to the second, i.e. the narrow understanding of culture, but based on the concept of a sector or industry, with the result that the creative process itself is not a conceptual determinant, but what becomes is the membership of a particular sphere of economic activity which could become parameterized using the methods of economic analysis. This approach allows to consider cultural activity in an economic perspective and define operationally intangible items of human creative activity in the field of art and thus define the scope of data for quantitative analyzes.

However, the culture industry is not the same as the creative industry. It is worth noting that the creative industries is a broader concept of cultural industries, as in the case of cultural industries the extract is made on the basis of end products produced as a result of the involvement of human activities 
of a creative nature carrying defined symbolic, aesthetic and emotional values being the manufacturer's intellectual property, which is a goal of consumption itself. However, in the definition of the creative industries are located products, the creation of which was dependent not only on factors related to meeting the needs of the author to produce the media following a setting inside his creative process, but also products resulting from the deliberate search for the creator of ways of expression (through product or service) oriented for material profit.

However, unlike the cultural industries, the concept of creative industries is very young and has been disseminated in publications of such foreign authors as R. Caves (2000), R. Florida (2002, 2011), PH Ray, and S.R. Anderson (2000) or D. Throsby (2011) and A. Nail Polish (2010), T. Stryjakiewicz 2008) or J. Szomburg (2002), therefore there are non-identical subject sectors of culture and creative industries.

In order to illustrate the differences, some of the most cited definitions of creative industries have been presented. The Department for Culture, Media and Sport (DCMS1) in its report on the creative industries defines them as "industries which are the source of the creativity of individuals, in skills and talent and which have the potential to create wealth and jobs through the creation and use of intellectual property". DCMS lists 11 creative sectors, which include visual arts, performances, film industry, radio and television, games/ software, the music industry, the book market, press market, industry design, architectural market, the advertising market. Similar to the above classification there is also a classification accepted by the UNCTAD2, according to which creative industries consist of four categories of industries: heritage, arts, media and utility projects.

Probably the broadest definition was adopted by the World Intellectual Property Organisation (WIPO). According to WIPO, the creative sector are all industries whose activities take into account the creation, production, manufacture, presentation, broadcast, exhibitions, distribution and sale of goods protected by copyright (Nowak 2010).

1 DCMS Investing in creative industries - a guide for local authorities, UK Government, Department of Culture, Media and Sport (DCMS), London 2009.

2 UNTCAD (United Nations Conference on Trade and Development). 


\section{Culture of coaching in the area of creative industries sector in the context of the creative class}

Creating in a specific place and environment a cluster of creative people, companies, institutions and infrastructure (Klasik 2009, p. 32), promotes the formation of the creative class.

With regard to the formation of the creative class, coaching culture is of particular importance.

The basic features of a coaching culture are oriented at development and feedback relationships based on trust, support and commitment. In the literature, the most important and widely described feature of the culture of coaching is oriented at development. This follows from the basic assumptions of human resources management concept, according to which employed workers are a strategic resource of organizations, in which we not only should, but first and foremost it is worth investing. Therefore, it is important to improve the potential of all employees and, importantly, treating it as an integral part of the development of the entire organization.

However, as important as the orientation at development are relationships based on trust, support and commitment. Coaching relationships are based on mutual agreement and trust of their participants. The leader coach builds a relationship based on their knowledge of specific behaviours which cause that between an employee and manager there is established a strong thread of understanding.

For the employee to be engaged, we should create for them an appropriate environment that will give them the opportunity for full engagement. For this purpose, their chief-coach must reach the reserves of the true mission of the given employee, get to know their values, which they often hide. De facto, often the employee himself is not aware of what he really is able to get involved in. When a leader learns the true mission and values of the staff and will give the opportunity to accomplish this mission and to be in line with their values, there is an environment created conducive to engagement that is strong and stable. Therefore, implementing a culture of coaching points to what kinds of behaviour build trust. Attention is also drawn to the fact what elements are important for this trust to emerge.

Hence, in the shaping a relation between the coach representing the coaching culture and the creative class representative customer, the needs and expectations of representatives of creative classes become important (see: Meconium 2010, p. 52). The coach in respect to a particular class should have powers allowing 
for appropriate support (Smółka 2011, p. 12). Furthermore, specific "goals, preferences, values and expectations of the representatives of the class will have an impact on what forms of support offered by the coach will be accepted by the recipient" (Smółka 2011, p. 12). Coach should have the necessary competence, skills and relational abilities associated with initiating relationships, their retention, development, and approach to their completion.

In shaping interpersonal relationships, their properties related to the intangible nature of the evaluation of the actions by the representatives of the creative class should be taken into account. Due to the fact that relationships do not arise spontaneously, but require action in the sphere of their initiation, maintenance, improvement and development, therefore they should be properly managed. In addition, goals and expectations, as well as the obtained value of the relationship is changing with the development of relations. Due to the natural tendency for relations to decay in the absence of interaction between the parties one should counteract the disappearance of the relationship. The disappearance of the relationship may be affected by: the fading possibilities of partners, inactivity, opportunistic attitude or loss of confidence on the part of representatives of the creative class. (Michałowska, Kotylak, Danielak 2015, p. 60). In shaping the relationship between the client and the coach we have to deal with the change of attitudes, behaviours, methods and concepts of operation. Also we face changing goals, values, expectations and factors motivating the customer to take action. Strong personal commitment of the coach and the client has a direct bearing on the quality and value of the relationship (cf. Boyce, Jackson, Neal 2010, p. 918).

Therefore, according to J. Passmore and K. Jastrzębska (2011, p. 96), „coaching culture is a culture in which coaching, that is, reflecting and provocative questions, is executed by all employees and key partners in order to develop understanding, institutions and sense of personal responsibility of those who are responsible for implementing organizational goals".

Coaching culture is most often defined in opposition to the traditional organization of human labour (Fordism3). It is therefore opposed to the traditional model of coaching, perceived as static and schematic. Traditional coaching is based on organizational behaviour governed mainly by the instructions, codes and regulations, and the basis for evaluating their value is formal compliance with the guidelines. Organisational behaviour arising from

3 Fordism - system of mass production and consumption. 
the creation of a culture of coaching is built on a canvas of ethical responsibility and shared values, their effectiveness can be measured by the degree of achievement of agreed objectives, but also as a contribution to the development team, building its meaning, laying out new directions, confirming identity, but also its questioning, putting into question the apparent obviousness, building alternatives, the reformulation of the mission.

While in the first model the members of the organization can be compared in terms of quantifiable criteria, and their own goals are taken into account only in the context of subsidiarity in relation to the organization with so much in the second - advantage in itself is a quality difference and diversity, not giving up to be reduced to a common denominator, but creatively participating in developing a complex harmony, where individual goals and values communicate, complementing each other $(2011,2014)$.

Referring therefore the ideas of the coaching culture to the idea of the creative class of R. Florida (2001, 2005, p. 34), i.e. the three main components, the so-called 3T (talent, tolerance and technology) covering:

- the potential of technology - R. Florida accepted that close location of businesses gives them the advantages of cooperation, that some activities require direct contact between representatives of companies. Technology as a feature of the city is here a function of the concentration of innovation and high technology enterprise, operating in the region,

- potential talent-a source of creative capital are creative units, forming a creative class. R. Florida explains that these are the people who "create meaningful new forms" and classified them as: scientists and engineers, university professors, poets and writers, artists, entertainers, actors, designers and architects, as well as leaders of the "fashionable societies": the authors of factual literature (nonfiction writers), editors and media people, influential figures in popular as well as elite culture, think tanks and any other opinion leaders. In addition, the creative class includes professionals from the fields of technology, financial services, legal, management and medicine - people whose work involves creative problem-solving and finding innovative solutions,

- potential of tolerance - for research purposes R. Florida defines tolerance as openness, diversity and friendliness towards people of different races, nationalities and choosing different paths in life. According to R. Florida not only economic reasons count for people but also a lifestyle. They do not choose the place where they want to live only on the basis of available jobs and the amount of possible earnings. Creative, educated people prefer friendly, innovative, tolerant and diverse places. 
Thus, the concept of building the creative class model based on diversity and unconventionality, which coaching culture offers, is the one that should be taken as corresponding to the expectations of people forming the centre of the class. Activating people interested in the functioning in the different sectors of creative industry built on the basis of the creative class is a key element in the success of their development.

\section{Summary}

In line with the model of human capital the essence of the implementation of the personal function is to invest in workers and care for their development and enhancing the knowledge resources of the organization. This means that in the management of representatives of the creative class, the concept of human capital is applied, for which significant is a coaching, supportive management style and management function creating a space for discussion and knowledge sharing, as well as the creation of ideas.

Among the key needs of the creative industries sector workers belonging to the creative class, we should note the continuing need for education and the ability to take on challenges and pursue their own passions and professional interests. Moreover, from the point of view of the functioning of businesses and other entities of the creative industries sector it is also important that people categorized as talents have a relatively large impact on the results achieved by the organizations.

Considering the development of the creative class and the need to stimulate workers' innovation in the creative industries and the consequent implications for human capital management, we should refer to the principles of the Manifesto of Memphis, which were worked out by representatives of the creative class at the summit in 2003. The document highlighted, among other things, that the culture of coaching is seen as an important factor in stimulating the development of creativity of the representatives of the sector, in particular those of its elements which are based on partnership gain in importance.

In practice, the use of coaching has many benefits in the form of motivation to change, the inspiration for more creative activities, more rapid adaptation to changing conditions, use to an even greater extent their own and other capabilities as well as new challenges (Mróz 2013, p. 84) .

In conclusion, features of the representatives of the creative class are to some extent consistent with the characteristics of coaching culture, which, combined with the main aim of the work of the coach, which is the distribution or practical 
use of knowledge, is an important area for the development of enterprises and organizations of creative industries sector.

\section{Summary}

Coaching culture in the context of the emergence of creative class The aim of the paper is to present on the basis of the study of literature the essence of coaching, the creative industries in the modern economy, the culture of coaching in relation to the creative class as well as issues relating to the development of relations between the client and the coach.

The study also pointed out the differences between coaching, counselling and consulting, distinguishing features of modern coaching and highlighted the factors affecting the process of shaping the relationship between the client and the coach.

With regard to the creative class coaching extends its alternative development of people and their organizations, based on the values of communication, acceptance of diversity and individuality, strengthening the sense of subjective efficacy and integrity, while expanding individual consciousness. As a result, this enhances the effect of stimulating creativity, which directly affects the development of the creative class as an essential element of the proper functioning of an important sector of the economy, which is the creative industry.

Keywords: creative industry, coaching culture, creative class

\section{Streszczenie}

Kultura coachingu w kontekście powstawania klasy kreatywnej Celem artykułu jest ukazanie na podstawie studiów literatury istoty coachingu, przemysłów kreatywnych we współczesnej gospodarce, kultury coachingu w odniesieniu do klasy kreatywnej oraz zagadnień dotyczących kształtowania relacji pomiędzy klientem a coachem.

W opracowaniu ponadto wskazano na różnice pomiędzy coachingiem, doradztwem i konsultingiem, wyróżniki współczesnego coachingu oraz zwrócono uwagę na czynniki mające wpływ na proces kształtowania relacji pomiędzy klientem a coachem. 
W odniesieniu do klasy kreatywnej coaching wysuwa swoją alternatywę rozwoju ludzi i ich organizacji, opartą na komunikacji wartości, akceptacji różnorodności i indywidualności, wzmacniania poczucia podmiotowej sprawczości i integralności, przy jednoczesnym poszerzaniu indywidualnej świadomości. W rezultacie wzmacnia to efekt pobudzania kreatywności, co bezpośrednio oddziałuje na rozwój klasy kreatywnej stanowiącej niezbędny element poprawnego funkcjonowania ważnego sektora gospodarki jakim jest przemysł kreatywny.

\section{Słowa \\ kluczowe: przemyst kreatywny, kultura coachingu, klasa kreatywna}

\section{References}

1. Adorno T. W., Horkheimer M. (2002), Dialectic of Enlightenment, Trans, Edmund Jephcott, Stanford, Stanford UP.

2. Adorno T. W. (1999), Podsumowanie rozważań na temat przemystu kulturowego, w: T. W. Adorno (oprac.), Sztuka i sztuki. Wybór esejów, Warszawa.

3. Boyce L.A., Jackson R.J., Neal L.J. (2010), Building successful leadership coaching relationships: Examining impact of matching criteria in a leadership coaching program, "Journal of Management Development", Vol. 29 Iss. 10.

4. Caves R. (2002), Creative industries: contracts between art and commerce, Harvard University Press, London.

5. Clutterbuck D. (2009), Coaching zespołowy, Dom Wydawniczy Rebis, Poznań.

6. Clutterbuck D., Megginson D. (2004), Techniques for Coaching and Mentoring, Publishing Taylor \& Francis, Boston.

7. Czaplewski J. (2011), Dobra informacyjne i ich podstawowe cechy ekonomiczne. w: Zeszyty Naukowe nr 650 - Ekonomiczne Problemy Usług nr 67, Tom I, Wydawnictwo Naukowe Uniwersytetu Szczecińskiego, Szczecin.

8. Czarkowska L.D. (2011), Filary coachingu i sześć dróg rozwoju organizacji, w: Coaching, katalizator rozwoju organizacji, Warszawa.

9. Dilths R. (2006), Od Przewodnika do Inspiratora. Coaching przez duże "C", PINLP, Warszawa.

10. Drab-Kurowska A. (2014), Ocena systemu szkoleń pracowników na przykładzie wybranych przedsiębiorstw funkcjonujacych na obszarze goleniowskiego parku przemysłowego (GPP), Zeszyty Naukowe nr 840 - Ekonomiczne Problemy Usług nr 114, Rola kapitału ludzkiego w rozwoju społeczno-gospodarczym regionu, Wydawnictwo Naukowe Uniwersytetu Szczecińskiego, Szczecin.

11. Fustec A., Fradin J. (2001), L'entreprise neuronale, Paryż. 
12. Florida R. (2002), The rise of the Creative Class, and how it's transforming work, Community and Everyday Life, New York.

13. Florida R. (2001), Narodziny klasy kreatywnej, Narodowe Centrum Kultury, Warszawa.

14. Gwóźdź A. (2010), Od przemystów kultury do kreatywnej gospodarki, Narodowe Centrum Kultury, Warszawa.

15. International Coach Federation, Ethics and regulations, http://www. coachfederation.org/about-icf/ethics/ (20.06.2011 - access date).

16. Klasik A. (2009), Przemysty kreatywne oparte na nauce i kulturze, w: A. Klasik (oprac.), Kreatywne miasto - kreatywna aglomeracja, Wydawnictwo Akademii Ekonomicznej w Katowicach.

17. Łychmus P. (2010,) Coaching oparty na wiedzy w treningach kierowniczych, Warszawa.

18. Maslow A. (2006) Motywacja i osobowość, Warszawa.

19. Michałowska M., Kotylak S., Danielak W. (2015), Forming relationships on the e-commerce market as basis to building loyalty and create value for the customer. Empirical findins, „Management”, Vol. 10, No. 1.

20. Mróz J. (2013), Coaching i mentoring wobec współczesnych wyzwań w rozwoju pracowników, Nauki o zarządzaniu, „Management Sciences” nr 3 (16).

21. Mukoid E. (2010), Język coachów, języki coachingu, Referat wygłoszony na Konferencji Język 3. Tysiąclecia, Kraków, http://mukoid.com/articles/ more/kultura-coachingu (02.03.2014 - access date).

22. Mukoid E., Kultura coachingu w kontekście zarzadzania instytucjami kultury, http://mukoid.com/articles/more/kultura-coachingu (02.03.2014 access date).

23. Passmore J., Jastrzębska K. (2011), Tworzenie kultury coachingowej: ścieżka rozwoju organizacyjnego, "Coaching Review”, nr 1.

24. Pilipczuk P. (2010), Coaching refleksja nad teoria a obszary praktycznych zastosowań w biznesie, "Coaching Review", nr 2.

25. Ray P.H., Anderson S.R.(2010), The Cultural Creative, Three Rivers Press, New York.

26. Rosinski P. (2011), Globalny coaching. Podejście zintegrowane, Warszawa.

27. Smółka P. (2010), Coaching umiejętności interpersonalnych: podejście oparte na dowodach, "Coaching Review”, nr 2.

28. Smółka P. (2011), Podejście oparte na dowodach w coachingu: istota oraz implikacje dla praktyki, "Coaching Review”, nr 1.

29. Stryjakiewicz T. (2008), Rozwój sektora kreatywnego w regionach metropolitalnych, w: J.J. Parysek (oprac.) Region społeczno-ekonomiczny i rozwój regionalny, Wydawnictwo Naukowe Bogucki, Poznan.

30. Szomburg J. (2002), (red.), Kultura i przemysty kulturowe szansa rozwojowa dla Polski, Wydawnictwo Instytutu Badań nad Gospodarką Rynkową CAK, Gdańsk. 
31. Thorpe S., Clifford J. (2004), Podręcznik coachingu, Dom Wydawniczy Rebis, Poznań.

32. Wilson C. (2001), Coaching biznesowy. Praktyczny podręcznik dla coachów, menedżerów i specjalistów HR, Warszawa.

33. Wilson C. (2011), Developing a coaching culture, „Industrial and Commercial Training", Vol. 43 Iss. 7.

34. Wittgenstein L. (2000), Dociekania filozoficzne, Warszawa.

35. Włodarkiewicz-Klimek H. (2013), Kapitat ludzki w ksztattowaniu zwinnosci organizacji opartych na wiedzy, w: G. Bełz, M. Hopej, A. Zgrzywa-Ziemak (oprac.), Wiedza w zarządzaniu wspótczesna organizacja, Prace Naukowe Uniwersytetu Ekonomicznego we Wrocławiu, nr 299.

36. Zubrzycka-Nowak M., Rybczyńska K., Monostori S. (2010), Czym (nie) jest coaching. Prawdy i mity o coachingu, Sopot. 